\title{
Impact of Blended Learning on Personal Effectiveness Factor of Managerial Effectiveness
}

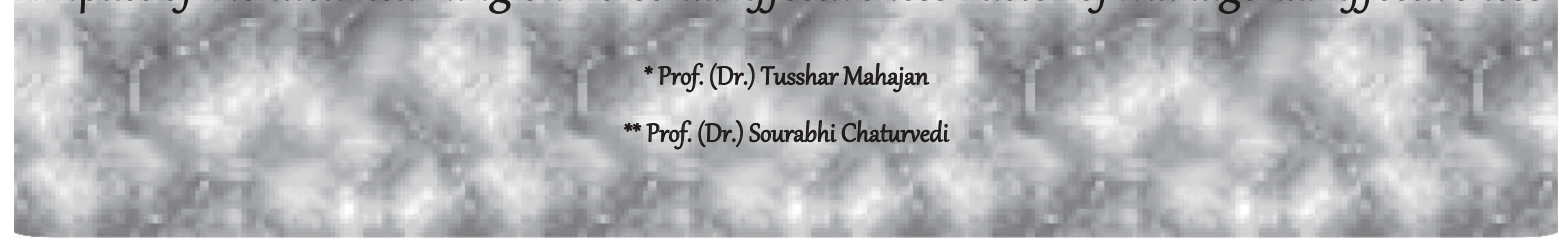

Effulgence

Vol. 13 No. 2

July - December, 2015

Rukmini Devi Institute of Advanced Studies

E-mail : effulgence@rdias.ac.in, Website : www.rdias.ac.in

http://effulgence.rdias.ac.in/user/default.aspx

https://dx.doi.org/10.33601/effulgence.rdias/v13/i2/2015/18-27

\begin{abstract}
There is a significant effect of Information Technology (IT) on business processes. Various IT tools help managers to perform managerial activities in better way. Due to this fact business organizations are implementing innovative techniques and ways of working. It requires continuous learning and training. For this purpose various organizations are using Blended Learning approach which combines traditional and online learning. The study examined impact of blended learning on personal effectiveness factor of managerial effectiveness through standardized managerial effectiveness scale, with reference to managers of Banking and Information Technology (IT) Sectors. Personal effectiveness refers to the individual effectiveness in which a person knows what he wants to do and accordingly works hard to achieve the target. The study interpreted that managers working in Banking Sector having experience less than or equal to five years are more effective than IT managers having same experience, in terms of Impact of Blended Learning on Personal Effectiveness Factor of Managerial Effectiveness.
\end{abstract}

Key Words: Information Technology, Blended learning, Managerial Effectiveness, PersonalEffectiveness Factor.

\section{INTRODUCTION}

$\mathrm{T}$ here is a significant effect of Information Technology (IT) on business processes. Various IT tools are being used by managers to perform managerial activities in better way. Due to this fact business organizations are implementing innovative techniques and ways of working. It requires continuous learning and training to achieve organizational goals and for this purpose various organizations are using Blended Learning approach. Blended learning combines different learning methodologies to complement each other for effective learning, like integration of traditional learning with online learning. Blended learning focuses on optimizing achievement of learning objectives by applying the "right" learning technologies to match the "right" personal learning style to transfer the "right" skills to the "right" person at the "right" time (Singh and Reed, 2001). Blended learning has ability to make learning process more efficient, easy, and effective, due to the fact that people have different learning styles.

Considering today's competitive and fast changing environment, every organization is trying to maximize effectiveness in terms of the entire organization, individual, managerial etc. Managerial effectiveness helps in organizational goal(s) achieving through the coordinated efforts. According to Reddin (1970) "Managerial effectiveness is the extent to which a manager achieves the output requirements related to his position, what he achieves rather than what he does". Campbell (1970) defined it as "Any set of managerial actions that are optimal for identifying, assimilating and utilizing internal and external resources with the aim of sustaining the functioning of the unit for which the manager is responsible". It represents a manager's capability to achieve desired results through his skills and by optimally utilizing all available potential resources like human resources, material resources, financial resources, etc. Success of an organization and achievement of its predetermined goals depends on effectiveness of its managers.

In this highly competitive and technologically fast changing environment, managers are required to update themselves about new techniques and technologies. Hence they should acquire knowledge and then distribute the knowledge acquired among their team and fellow-workers. Training and learning are required for the purpose for enhancing skills and effectiveness of managers. In this context, blended learning is being used by various organizations to improve 
effectiveness of their managers. The study examined impact of blended learning on personal effectiveness factor of managerial effectiveness, with reference to managers of Banking and Information Technology (IT) Sectors. Personal effectiveness refers to the individual effectiveness in which a person knows what he wants to do and accordingly works hard to achieve the target. Personal effectiveness indicates that a manager has characteristics like identifying problems effectively, analyze problems effectively, knows exactly what she/he wants to do, coordinates various task groups, can work well under pressure, and can handle conflicting situations effectively. Pareek (1988) developed an instrument and used personal effectiveness and managerial effectiveness in the same sense and meaning. If a person was found effective on the instrument, he was likely to be an effective manager. According to Leslie et al. (2010) personality help to explain the managerial capabilities and role behaviors a manager is most likely to acquire, and personality is associated with managerial effectiveness.

\section{LITERATURE REVIEW}

In a study, Alireza and Sheela (2010) concluded that the blended learning entails a relatively innocuous set of techniques and leads to innovative instructional design, to achieve effectiveness without increasing costs. According to Scryn (2010) blended learning has the proven potential to increase effectiveness and efficiency of meaningful learning experiences. Patil and Shinde (2010) reported that the traditional learning methodology needs a smooth but sustainable transformation and for this purpose blended learning approach can be used. Blended learning approach has ability to make learning process more efficient, easy, socialized, and well-organized. Singh and Reed (2001) found that organizations are beginning to understand strategic impact of blended learning on critical business processes. According to the study, blended learning is time and cost effective approach.

Pathak et al. (2011) studied the relationship of managerial effectiveness with motivational climate and leadership effectiveness of managers from public sector banks in India. For managerial effectiveness, managers gave first three ranks to: competency and responsibility, good work ethics, and work quality. Analoui et al. (2010) explored the ways/factors which influence and/or determine the effectiveness of the senior management in the Muscat Municipality, Oman, by assessing the perception of senior managers concerning the influences (parameters) on their effectiveness. These are: the awareness, perceptions, skills, organizational standards, motivation, degree of demands and constraints, and the presence of choices and opportunities for effectiveness.
Dhar et al. (2005) found that managerial creativity significantly affected managerial effectiveness. Managers with high managerial creativity have significantly high managerial effectiveness. Pickett (2000) reported the traits of an effective manager in requisites of embracing change, attending to external realities, creating power, promoting a coaching style, expanding job responsibilities, creating expertise, driving out fear, exhibiting readiness for an entrepreneurial environment, keeping balance, maintaining a sense of continuity and demonstrating emotional maturity. According to Jain (2000), different factors like; the success of training and development programs, the creation of organizational environment where employees work willingly and effectively, motivation and moral of employees, efficiency and effectiveness of systems/procedures, adaptability, flexibility and productivity can help for assessing managerial effectiveness.

Dhar et al. (2000) reported that managerial effectiveness consists of functional, personal and interpersonal effectiveness. Functional effectiveness represents a manager's ability to execute all managerial functions (Planning, organizing, coordinating, controlling, etc.) effectively. Personal effectiveness represents individual effectiveness i.e. self awareness and self responsibility through which a person works hard to achieve the aim. Interpersonal effectiveness indicates interpersonal skills and good interpersonal relations, which help manager to motivate people to put their best efforts with available resources. Dhar et al. (2000) showed that personal effectiveness means a manager has characteristics like identifying problems effectively, analyze problems effectively, knows exactly what she/he wants to do, coordinates various task groups, can work well under pressure, and can handle conflicting situations effectively. According to Rangnekar (1999), there are certain personality traits leading to managerial effectiveness, in context of Indian managers. The highest rated traits were co-operative, intelligent and energetic, while the lowest ones were aggressive, dominant and conforming.

\section{RESEARCH METHODOLOGY}

The study represents exploratory research, as it explored Impact of Blended Learning (BL) on Personal Effectiveness Factor (PEF) of Managerial Effectiveness (ME), with respect to managers of Banking and Information Technology Sectors.

Objectives of the study: The study was based on following three objectives- 
- To analyze impact of blended learning on Personal Effectiveness Factor of managerial effectiveness with respect to Banking and Information Technology Sectors.

- To study impact of blended learning on Personal Effectiveness Factor of managerial effectiveness with respect to experience of managers.

- To measure impact of blended learning on Personal Effectiveness Factor of managerial effectiveness with respect to gender of managers.

The sample and the design: The respondents were managers from IT Sector and Banking Sector, based on the application of blended learning in their organization, from different cities of India like Pune, Mumbai, Noida, Ghaziabad, Gurgaon, Indore, and Bhopal. The sample size of the study was 320 . The tri-variate design (" $2 \times 2 \times 2$ " constitution) was adopted for the study to measure the effect of type of sector (Banking Sector and Information Technology Sector), gender (Male and Female) and experience ( $<=5$ years and $>5$ years) as independent variables on Personal Effectiveness Factor of Managerial Effectiveness as dependent variable. On this basis, the sample distribution is as shown below:

Table 1: Sample distribution

\begin{tabular}{|c|c|c|c|c|}
\hline \multirow[b]{2}{*}{ Gender } & \multicolumn{4}{|c|}{ Type of Sector } \\
\hline & \multicolumn{2}{|c|}{ Banking Sector } & \multicolumn{2}{|c|}{ IT Sector } \\
\hline & Experience $<=5$ years & Experience $>5$ years & Experience $<=5$ years & Experience $>5$ years \\
\hline Male & $\mathbf{A}(40)$ & $\mathbf{B}(40)$ & $\mathbf{C}(40)$ & $\mathbf{D}(40)$ \\
\hline Female & $\mathbf{E}(40)$ & $\mathbf{F}(40)$ & $\mathbf{G}(40)$ & $\mathbf{H}(40)$ \\
\hline
\end{tabular}

The tools for data collection and analysis: Data collection was carried through Managerial Effectiveness Scale UUpinder Dhar, Santosh Dhar and Preeti Jain (2000). Manual for Managerial Effectiveness Scale. Agra: National Psychological Corporation. Reliability coefficient of the scale was found to be 0.9667 and validity was 0.98322 ], as shown in Appendix 1. For data analysis statistical tools ZTest and ANOVA Technique were applied at 5\% level of significance.

\section{RESULTS}

For the present study, based on the objectives, six problems and twenty null hypotheses were formulated and tested using ANOVA Technique and Z-Test. The problems, hypotheses and are shown as follows (Respective results, in tabular form, are given as Annexure):

Problem 1: Is Personal Effectiveness Factor of Managerial Effectiveness a function of Gender and Sector in terms of Impact of Blended Learning?

$\mathrm{H}_{01}$ : Gender and sector do not interact in terms of Impact of Blended Learning on Personal Effectiveness Factor of Managerial Effectiveness.

The null hypothesis is accepted $(\mathrm{F}=.043, \mathrm{p}=.836)$.

$\mathrm{H}_{02}$ : Banking Sector male managers do not differ significantly from IT Sector male managers in terms of Impact of Blended Learning on Personal Effectiveness Factor of Managerial Effectiveness.

The null hypothesis is accepted $(\mathrm{Z}=1.356, \mathrm{p}=.177)$.

$\mathrm{H}_{03}$ : Banking Sector female managers do not differ significantly from IT Sector female managers in terms of Impact of Blended Learning on Personal Effectiveness Factor of Managerial Effectiveness.

The null hypothesis is accepted $(\mathrm{Z}=.952, \mathrm{p}=.343)$.

Problem 2: Is Personal Effectiveness Factor of Managerial Effectiveness a function of Gender and Experience in terms of Impact of Blended Learning?

$\mathrm{H}_{04}$ : Gender and experience do not interact in terms of Impact of Blended Learning on Personal Effectiveness Factor of Managerial Effectiveness.

The null hypothesis is accepted $(\mathrm{F}=.946, \mathrm{p}=.332)$.

$\mathrm{H}_{05}$ : Male managers having experience $<=5$ years do not differ significantly from female managers having experience $<=5$ years in terms of Impact of Blended Learning on Personal Effectiveness Factor of Managerial Effectiveness.

The null hypothesis is accepted $(\mathrm{Z}=.256, \mathrm{p}=.798)$. 
$\mathrm{H}_{06}$ : Male managers having experience $>5$ years do not differ significantly from female managers having experience $>5$ years in terms of Impact of Blended Learning on Personal Effectiveness Factor of Managerial Effectiveness.

The null hypothesis is accepted $(\mathrm{Z}=1.603, \mathrm{p}=.111)$.

Problem 3: Is Personal Effectiveness Factor of Managerial Effectiveness a function of Sector and Experience in terms of Impact of Blended Learning?

$\mathrm{H}_{07}$ : Experience and sector do not interact in terms of Impact of Blended Learning on Personal Effectiveness Factor of Managerial Effectiveness.

The null hypothesis is rejected $(\mathrm{F}=17.471, \mathrm{p}=.000)$.

Hence, experience and sector interact in terms of Impact of Blended Learning on Personal Effectiveness Factor of Managerial Effectiveness.

$\mathrm{H}_{08}$ : Banking Sector managers having experience $>5$ years do not differ significantly from Information Technology (IT) Sector managers having experience $>5$ years in terms of Impact of Blended Learning on Personal Effectiveness Factor of Managerial Effectiveness.

The null hypothesis is accepted $(\mathrm{Z}=-1.749, \mathrm{p}=.082)$.

$\mathrm{H}_{09}$ : Banking Sector managers having experience $<=5$ years do not differ significantly from Information Technology Sector managers having experience $<=5$ years in terms of Impact of Blended Learning on Personal Effectiveness Factor of Managerial Effectiveness.

The null hypothesis is rejected $(\mathrm{Z}=3.923, \mathrm{p}=0.000)$.

Hence, Banking Sector managers having experience $<=5$ years differ significantly from IT Sector managers having experience $<=5$ years and Banking Sector managers are more effective than IT Sector managers in terms of Impact of Blended Learning on Personal Effectiveness Factor of Managerial Effectiveness.

Problem 4: Is Personal Effectiveness Factor of Managerial Effectiveness a function of Gender, Sector and Experience in terms of Impact of Blended Learning?

$\mathrm{H}_{010}$ : Gender, experience and sector do not interact in terms of Impact of Blended Learning on Personal Effectiveness Factor of Managerial Effectiveness.
The null hypothesis is accepted $(\mathrm{F}=.336, \mathrm{p}=.563)$.

$\mathrm{H}_{011}$ : Banking Sector male managers having experience $>5$ years do not differ significantly from IT Sector male managers having experience $>5$ years in terms of Impact of Blended Learning on Personal Effectiveness Factor of Managerial Effectiveness.

The null hypothesis is accepted $(\mathrm{Z}=-.966, \mathrm{p}=.337)$.

$\mathrm{H}_{012}$ : Banking Sector female managers having experience $>5$ years do not differ significantly from Information Technology Sector female managers having experience $>5$ years in terms of Impact of Blended Learning on Personal Effectiveness Factor of Managerial Effectiveness.

The null hypothesis is accepted $(\mathrm{Z}=-1.474, \mathrm{p}=.145)$.

$\mathrm{H}_{013}$ : Banking Sector male managers having experience $<=5$ years do not differ from IT male managers having experience $<=5$ years in terms of Impact of Blended Learning on Personal Effectiveness Factor of Managerial Effectiveness. The null hypothesis is rejected $(\mathrm{Z}=2.707$, $\mathrm{p}=.008)$.

Hence, Banking Sector male managers having experience $<=5$ years differ significantly from Information Technology Sector male managers having experience $<=5$ years in terms of Impact of Blended Learning on Personal Effectiveness Factor of Managerial Effectiveness and Banking Sector male managers are more effective than Information Technology Sector male managers in terms of Impact of Blended Learning on Personal Effectiveness Factor of Managerial Effectiveness.

$\mathrm{H}_{014}$ : Banking Sector female managers having experience $<=5$ years do not differ significantly from Information Technology Sector female managers having experience $<=5$ years in terms of Impact of Blended Learning on Personal Effectiveness Factor of Managerial Effectiveness.

The null hypothesis is rejected $(\mathrm{Z}=3.253, \mathrm{p}=.002)$.

Hence, Banking Sector female managers having experience $<=5$ years differ significantly from Information Technology Sector female managers having experience $<=5$ years in terms of Impact of Blended Learning on Personal Effectiveness Factor of Managerial Effectiveness and Banking Sector female managers are more effective than Information Technology Sector female managers in terms of Impact of Blended Learning on Personal Effectiveness Factor of Managerial Effectiveness. 
Problem 5: Is Personal Effectiveness Factor of Managerial Effectiveness a function of Gender in terms of Impact of Blended Learning?

$\mathrm{H}_{015}$ : There is no significant effect of gender on Personal Effectiveness Factor of Managerial Effectiveness in terms of Impact of Blended Learning.

The null hypothesis is accepted $(\mathrm{F}=1.809, \mathrm{p}=.180)$.

$\mathrm{H}_{016}$ : Male managers do not differ significantly from female managers in terms of Impact of Blended Learning on Personal Effectiveness Factor of Managerial Effectiveness.

The null hypothesis is accepted $(\mathrm{Z}=1.311, \mathrm{p}=.191)$.

Problem 6: Is Personal Effectiveness Factor of Managerial Effectiveness a function of Sector in terms of Impact of Blended Learning?

$\mathrm{H}_{017}$ : There is no significant effect of sector on Personal Effectiveness Factor of Managerial Effectiveness in terms of Impact of Blended Learning.

The null hypothesis is accepted $(\mathrm{F}=2.740, \mathrm{p}=.099)$.

$\mathrm{H}_{018}$ : Bank managers do not differ significantly from IT managers in terms of Impact of Blended Learning on Personal Effectiveness Factor of Managerial Effectiveness.

The null hypothesis is accepted $(\mathrm{Z}=1.616, \mathrm{p}=.107)$.

Problem 7: Is Personal Effectiveness Factor of Managerial Effectiveness a function of Experience in terms of Impact of Blended Learning?

$\mathrm{H}_{019}$ : There is no significant effect of experience on Personal Effectiveness Factor of Managerial Effectiveness in terms of Impact of Blended Learning.

The null hypothesis is accepted $(\mathrm{F}=1.114, \mathrm{p}=.292)$.

$\mathrm{H}_{020}$ : Managers having experience $<=5$ years do not differ significantly from managers having experience $>5$ years in terms of Impact of Blended Learning on Personal Effectiveness Factor of Managerial Effectiveness.

The null hypothesis is accepted $(\mathrm{Z}=1.028, \mathrm{p}=.305)$.

\section{Summary of the results:-}

1. Experience and sector interact in terms of Impact of Blended Learning on Personal Effectiveness Factor of Managerial Effectiveness.

2. Managers (Male and female) working in Banking Sector having experience $<=5$ years are more effective than managers (Male and female) working in Information Technology Sector having experience $<=5$ years in terms of Impact of Blended Learning on Personal Effectiveness Factor of Managerial Effectiveness.

\section{DISCUSSION}

The results derived from the present study have resemblance, to varied extent, with certain similar researches. According to Goodridge (2001) and Masie (2002), the blended-learning approach offers organizations both the cost savings associated with e-learning and the personal touch of classroom instruction. They mentioned that organizations are increasingly turning toward blended learning rather than e-learning alone. Nagura and Arakawa (2003) reported effectiveness of blended learning in management skill training and found three major aspects: First, for training human resources to improve management skills, e-based knowledge input and the group training (Traditional training) both are required. Second, for this participants strongly supported blended learning approach. Third, the blended learning has the potential to increase the overall effects and efficiency of the training. Thus blended learning helps for enhancing skills of managers. Bersin (2005) found that blended learning can be used to develop competence and integrating it into a company's workforce for competitive advantage. Leveraging competence in today's markets can lead to success when executing business strategies and it can be achieved effectively by using blended learning approach. The above studies indicate that blended learning is beneficial for organizations and improves managerial skills. Also our study showed that banking sector and IT sector are using blended learning to enhance managerial effectiveness of managers.

Chaturvedi (2008) concluded that service sector employees had a positive perception towards e-learning and they perceived e-learning as a better training medium. According to Parashar (2008), type of organization affects Personal Effectiveness Factor (PEF) of Managerial Effectiveness. Nathwani (2004) showed that the managerial effectiveness of nationalized and private sector banks was very much high and satisfactory. According to Choudhari (2003) higher effectiveness of bank managers than managers of other sectors, is associated with timely completion of jobs, better 
service transaction and better customer interactions. Dharmani (1990) studied managerial effectiveness in the leading banks of Himachal Pradesh (India) and found that personal factors contribute to managerial effectiveness. In accordance with above studies, results of the present study showed that blended learning benefited both bank managers and IT managers but by the application of blended learning, Personal Effectiveness Factor of Managerial Effectiveness of bank managers is more in comparison to IT managers.

According to Parashar (2008), type of organization and age interactively affect PEF. The results of the study carried out by Sharma (2005) showed that score of PEF was found to be higher in executives with 10 years and less job experience, favorable organizational climate and high emotional intelligence. Delis et al. (2001) reported that age is related to decline in executive functioning. A study carried out by Sinha et al (2000) revealed that psychological barriers to technological change were found to be positively related to age and length of service. Similar to above studies, our results showed that using blended learning, Personal Effectiveness Factor of Managerial Effectiveness of banking managers having experience $<=5$ years was found to be more than IT managers having experience $<=5$ years.

A study by Sackey et al (2011) explored the relationship between occupational stress and the perceived effectiveness of men and women managers in Ghanaian organizations. The results showed that there was no significant difference between their managerial effectiveness and that of the male. Chaturvedi (2008) reported that males perceive E-Learning as a better training medium than their female counterparts. Kenworthy (2005) conducted a research for developing Managerial Effectiveness. The results highlighted that the female participants showed a significantly greater behavior change than males in Achievement Orientation. Similar to above studies, no significant effect was found with respect to gender on Personal Effectiveness Factor of Managerial Effectiveness on bank and IT managers through the application of blended learning.

\section{CONCLUSIONS}

The study was carried out to determine Impact of Blended Learning on Personal Effectiveness Factor of Managerial Effectiveness. Hence in accordance with the objectives of the study and from the derived results, following conclusions were drawn: The first objective was with respect to sector and it was found that blended learning helped bank managers to enhance Personal Effectiveness Factor more than IT managers, the second objective was related to experience of managers and bank managers having experience less than or equal to five years showed more personal effectiveness than IT managers having experience less than or equal to five years, the third objective was concerned with gender of managers and no significant difference was found between male and female managers with reference to Impact of Blended Learning on Personal Effectiveness Factor of Managerial Effectiveness.

Hence, in general from the study it can be concluded that Banking Sector managers (Male and female) having experience less than or equal to five years were found to be more effective managers than IT managers, in terms of Impact of Blended Learning on Personal Effectiveness Factor of Managerial Effectiveness.

\section{IMPLICATIONS OF THE STUDY}

The study implied that Banking Sector managers are more effective than Information Technology Sector managers and specially managers having experience less than or equal to five years are more effective managers, in terms of Impact of Blended Learning on Personal Effectiveness Factor of Managerial Effectiveness. Also the study reported significant Impact of Blended Learning on Personal Effectiveness Factor of Managerial Effectiveness (ME) for managers of Banking Sector as well as Information Technology (IT) Sector managers. Hence organizations through Human Resource Development (HRD) department should design and conduct training/learning programs to elicit the effectiveness of managers using the blended learning approach.

With respect to blended learning, bank managers showed more personal effectiveness than IT managers. In banks, in case of personal effectiveness characteristics managers showed competence and responsibility, good work ethics, and work quality. The findings also indicated that to be an effective manager, bank managers achieve a distinct advantage due to the commitment and attentiveness towards customers. Therefore it is necessary for IT mangers to pay stress for enhancing personal effectiveness. In case of experience, bank managers with experience less than or equal to five years showed more personal effectiveness than managers with experience greater than five years. Thus highest performers among mangers were less experienced managers, due to their positive attitude, more enthusiasm towards technology delivered classes and they have higher conscientiousness and therefore they are organized and disciplined and this leads to better effectiveness. Higher experienced managers are generally less open in exploring new options for learning and their psychological barriers for technological change can also lead to lower participation in 
blended learning programs. Hence the study implied that more experienced managers should emphasize on learning and specially blended learning approach to enhance their effectiveness.

\section{REFERENCES}

1. Alireza B. And Sheela (2010). Blended learning as an innovative instructional design. Retrieved July 20, 2014 from http:/ /www.aiaer.net.

2. Analoui Farhad, Abdulla A. Abmed, Nada Kakabadse (2010). Parameters of managerial effectiveness: The case of senior managers in the Muscat Municipality, Oman. Retrieved 20May2014 from www.emeraldinsight.com/journals.htm? Articleid $=1829528$

3. Bersin (2005). Blended learning 3tier approach for leadership skills. Retrieved on 30Oct.2013 from www.bersinassociates.com/free_research/Air_Products_3-1.pdf

4. Campbell, J.P. (1970). Managerial Behavior, Performance and Effectiveness. New York: McGraw Hill.

5. Chaturvedi, S. (2008). E-Learning as an Emerging Corporate Training Medium: Challenges and Opportunities. Ph.D. Thesis. Indore: Devi Ahilya Vishwavidyalaya.

6. Chaudhari, C.S. (2003). Leadership Behavior and Occupational Self Efficacy as Predictor of Managerial Effectiveness, Learned Helpless and Job Attitudes in Manufacturing and Service Sector Organizations. Ph.D. Thesis. Indore: Devi Ahilya Vishwavidyalaya.

7. Delis, D.C., Kaplan, E., and Kramer, J.H. (2001). DelisKaplan Executive Function System. San Antonio: TX: Psychological Corporation.

8. Dhar U., Chauhan V.S. and Pathak, R.D. (2005) Factorial Constitution of Managerial Effectiveness: Reexamining an Instrument in Indian Context. Journal of Managerial Psychology, 20(2), 164-177.

9. Dhar, U., Dhar, S. and Jain, P. (2000). Manual for Managerial Effectiveness Scale. Agra: National Psychological Corporation.

10. Dharmani, A.N. (1990). Managerial Effectiveness in Relation to Certain Personal Situational Variables in Public Sector Banks. Ph.D. Thesis. Punjab University.

11. Goodridge (2001). Cited in Derouin, Fritzsche and Salas (2005). E-Learning in Organizations. Journal of Management 31: 920

12. Jain, P. (2000). Development and Standardization of A Scale for Measuring Managerial Effectiveness. Indore: Prestige Institute of Management and Research.

13. Kenworthy John (2005). Developing managerial effectiveness: assessing and comparing the impact of development programmes using a management simulation or a management game. Retrieved on 23 May 2013 from http://www.coulthard.com/library/Files/ kenworthy_2005_developingmanagerialeffectiveness_si mulation.pdf

14. Leslie Jean B., Maxine Dalton, Chris Ernst and Jennifer Deal (2010). Managerial effectiveness in a global context. Retrieved 30 may 2012 from http://www.ccl.org/leadership/pdf/publications/ccl_ managerialeffectiveness.pdf

15. Masie, (2002). Cited in Derouin, Fritzsche and Salas (2005). E-Learning in Organizations. Journal of Management 31: 920

16. Nagura and Arakawa (2003). Effectiveness of blended learning in management skill training. Retrieved Apr. 20, 2014 from www.nri.co.jp/english/opinion/papers/2003/pdf/ $n$ 200369.pdf

17. Nathwani, R (2004). The Study of Customers' Preference and Managerial Effectiveness of Nationalized and Private Sector Banks. Ph.D. Thesis: Saurashtra University.

18. Parashar, S. (2008). Impact of Personality, Type of Organization and Age on Managerial Effectiveness. Ph.D. Thesis. Indore: Devi Ahilya Vishwavidyalaya.

19. Pareek, U. (1988). Organizational Learning Diagnostics. Measuring Organizational Climate, Academy of HRD, Ahmedabad.

20. Pathak R D, Dhamani A N and Pestonjee D M (2011). Managerial Effectiveness as Related to Organizational Climate and Leadership Effectiveness among Bank Employees in India. Retrieved October 20, 2013 from http://econpapers.repec.org/paper/iimiimawp/wp011 70.htm

21. Patil, S. Shinde, G. (2010). Transforming Indian higher education through blended learning approach. Retrieved 20May2011 from http://ieeexplore.ieee.org

22. Pickett, L. (2000). People make the difference. Industrial and Commercial Training, 32 (6), 225-229.

23. Rangnekar, S. (1999). A Study of Locus of Control and Learned Helplessness as Predictors of Managerial Effectiveness. Ph. D. Thesis. Indore: Devi Ahilya Vishwa Vidyalaya.

24. Reddin, W.J. (1970). Managerial Effectiveness. New York: McGraw Hill.

25. Sackey Jocelyn, Priscilla Boahemaa, and Mohammed A. Sanda (2011). Relational Impact of Job Stress on Gender Based Managerial Effectiveness in Ghanaian Organizations. World Academy of Science, Engineering and Technology, 60

26. Scryn (2010). Blended learning: Uncovering its transformative potential in higher education. Retrieved July 20, 2013 from http://www.oppapers.com/essays/Blended-LearningUncovering-Its-Transformative-Potential

27. Sharma, J. (2005). A Study of Emotional Intelligence, Job Experience and Organizational Climate as Determinants of Managerial Effectiveness and Organizational Commitment. 
Ph.D. Thesis. Indore: Devi Ahilya Vishwavidyalaya.

28. Singh and Reed (2001). Achieving Success with Blended Learning. Retrieved July 20, 2013 from www.chriscollieassociates.com/BlendedLearning.pdf
29. Sinha, B., Vohra, N., Singhal, S., Sinha, R.B. and Ushashree, S. (2000). Normative Predictions of Collectivist-Individualist Intentions and Behavior of Indians. International Journal of Psychology, 37, 309-320.

\section{Appendix 1: ME Scale}

Please assess each pair of statements with reference to your superior on a seven-point scale. Encircle your choice for each pair of the statements accordingly.

\begin{tabular}{|c|c|c|c|}
\hline 1 & $\begin{array}{l}\text { Know exactly what they want to } \\
\text { do. }\end{array}$ & $\begin{array}{lllllll}7 & 6 & 5 & 4 & 3 & 2 & 1\end{array}$ & $\begin{array}{l}\text { Do not know what they want to } \\
\text { do. }\end{array}$ \\
\hline 2 & $\begin{array}{l}\text { Coordinate various task groups } \\
\text { to achieve results. }\end{array}$ & $\begin{array}{llllllll}7 & 6 & 5 & 4 & 3 & 2 & 1\end{array}$ & $\begin{array}{l}\text { Do not coordinate various task } \\
\text { groups to achieve results. }\end{array}$ \\
\hline 3 & Can handle conflict effectively. & $\begin{array}{llllllll}7 & 6 & 5 & 4 & 3 & 2 & 1\end{array}$ & $\begin{array}{l}\text { Cannot handle conflict } \\
\text { effectively. }\end{array}$ \\
\hline 4 & Can work well under pressure. & $\begin{array}{lllllll}7 & 6 & 5 & 4 & 3 & 2 & 1\end{array}$ & $\begin{array}{l}\text { Cannot work well under } \\
\text { pressure. }\end{array}$ \\
\hline 5 & $\begin{array}{l}\text { Can identify problems } \\
\text { effectively. }\end{array}$ & $\begin{array}{llllllll}7 & 6 & 5 & 4 & 3 & 2 & 1\end{array}$ & $\begin{array}{l}\text { Cannot identify problems } \\
\text { effectively. }\end{array}$ \\
\hline 6 & $\begin{array}{l}\text { Cananalyzeproblems } \\
\text { effectively. }\end{array}$ & $\begin{array}{llllllll}7 & 6 & 5 & 4 & 3 & 2 & 1\end{array}$ & $\begin{array}{l}\text { Cannot analyze problems } \\
\text { effectively. }\end{array}$ \\
\hline
\end{tabular}

Dependent Variable: PEF $\quad$ Appendix 2: Table of ANOVA results for PEF

\begin{tabular}{|l|c|c|c|c|c|}
\hline Source & Sum of Squares & df & Mean Square & F & Sig. \\
\hline Corrected Model & $714.038^{a}$ & 7 & 102.005 & 3.494 & .001 \\
Intercept & 313375.613 & 1 & 313375.613 & 10734.457 & .000 \\
gender & 52.812 & 1 & 52.812 & 1.809 & .180 \\
sector & 80.000 & 1 & 80.000 & 2.740 & .099 \\
exp & 32.512 & 1 & 32.512 & 1.114 & .292 \\
gender* sector & 1.250 & 1 & 1.250 & .043 & .836 \\
gender* exp & 27.612 & 1 & 27.612 & .946 & .332 \\
sector * exp & 510.050 & 1 & 510.050 & $17.471 *$ & .000 \\
gender* sector * exp & 9.800 & 1 & 9.800 & .336 & .563 \\
Error & 9108.350 & 312 & 29.193 & & \\
Total & 323198.000 & 320 & & & \\
Corrected Total & 9822.388 & 319 & & & \\
\hline
\end{tabular}

$*$ Rejection at 5\% Significance Level 
Appendix 3: Table Showing Means, Standard Deviations and Z-values (For Impact of BL on PEF of ME)

\begin{tabular}{|l|l|l|l|}
\hline Managers $\longrightarrow$ & $\begin{array}{l}\text { Banking Sector } \\
\text { Managers } \\
\text { Mean=31.7938 } \\
\text { SD=5.95486 }\end{array}$ & $\begin{array}{l}\text { Managers with } \\
\text { exp.<=5 years } \\
\text { Mean=31.6125 } \\
\text { SD=5.54681 }\end{array}$ & $\begin{array}{l}\text { Male Managers } \\
\text { Mean=31.7000 } \\
\text { SD=5.26147 }\end{array}$ \\
\hline $\begin{array}{l}\text { IT Sector Managers } \\
\text { SD=5.08060 }\end{array}$ & $\mathrm{Z}=1.616$ & \\
\hline $\begin{array}{l}\text { Managers with } \\
\text { exp. } \\
\text { Mean=30.9750 } \\
\text { SD=5.55017 }\end{array}$ & & $\mathrm{Z}=1.028$ & \\
\hline $\begin{array}{l}\text { FemaleManagers } \\
\text { Mean=30.8875 } \\
\text { SD=5.81041 }\end{array}$ & & & \\
\hline
\end{tabular}

$5 \%$ level of significance

Appendix 4: Table Showing Means, Standard Deviations and Z-values (For Impact of BL on PEF of ME) with respect to gender, sector and experience.

\begin{tabular}{|c|c|c|c|c|c|c|}
\hline$\stackrel{\text { Managers }}{\longrightarrow}$ & $\begin{array}{l}\text { Banking Sector } \\
\text { Male } \\
\text { Managers, } \\
\text { Mean=32.2625 } \\
\mathrm{SD}=5.30522\end{array}$ & $\begin{array}{l}\text { Banking Sector } \\
\text { Female } \\
\text { Managers } \\
\text { Mean }=31.3250 \\
\text { SD }=6.54057\end{array}$ & $\begin{array}{c}\text { Banking Sector } \\
\text { Managers with } \\
\text { Exp }<=5 \\
\text { Mean }=33.1750 \\
\text { SD }=5.52503\end{array}$ & $\begin{array}{c}\text { Banking Sector } \\
\text { Managers with } \\
\text { Exp }>5 \\
\text { Mean }=30.2125 \\
\text { SD }=6.13290\end{array}$ & $\begin{array}{l}\text { Male } \\
\text { Managers with } \\
\text { Exp }<=5 \text { years } \\
\text { Mean }=31.7250 \\
\mathrm{SD}=5.66574\end{array}$ & $\begin{array}{l}\text { Male } \\
\text { Managers with } \\
\text { Exp }>5 \text { years } \\
\text { Mean }=31.6750 \\
\text { SD }=4.85948\end{array}$ \\
\hline $\begin{array}{l}\text { IT Sector Male } \\
\text { Managers, } \\
\text { Mean }=31.1375 \\
\text { SD }=5.18943\end{array}$ & $Z=1.356$ & & & & & \\
\hline $\begin{array}{l}\text { IT Sector } \\
\text { Female } \\
\text { Managers, } \\
\text { Mean=30.4500 } \\
\mathrm{SD}=4.97818\end{array}$ & & $\mathrm{Z}=.952$ & & & & \\
\hline $\begin{array}{l}\text { IT Sector } \\
\text { Managers with } \\
\text { Exp }<=5 \\
\text { Mean=29.8500 } \\
\mathrm{SD}=5.19030\end{array}$ & & & $Z=3.923 *$ & & & \\
\hline
\end{tabular}




\begin{tabular}{|l|l|l|l|l|l|l|}
\hline IT Sector & & & & & \\
Managers with & & & & & & \\
Exp $>5$ & & & & & \\
Mean=31.7375 & & & & & \\
SD=4.81754 & & & & & $\mathrm{Z}=0.256$ & \\
\hline Female & & & & & \\
Managers with & & & & & \\
Exp <=5 years & & & & & & \\
Mean=31.5000 & & & & & & \\
SD=5.45871 & & & & & & \\
\hline Female & & & & & & \\
Managers with & & & & & \\
Exp >5 years & & & & & \\
Mean=30.2750 & & & & & \\
SD=6.11488 & & & & & \\
\hline
\end{tabular}

$*$ Rejection at $5 \%$ level of significance

Appendix 5: Table Showing Means, Standard Deviations and Z-values (For Impact of BL on PEF of ME) of bank and IT managers.

\begin{tabular}{|c|c|c|c|c|}
\hline $\begin{array}{l}\text { Banking } \quad \text { Sector } \\
\text { Managers } \longrightarrow \\
\text { ITSector Mahagers }\end{array}$ & $\begin{array}{l}\text { Male Managers } \\
\text { Exp }<=5 \\
\text { Mean }=33.3750 \\
\mathrm{SD}=5.33343\end{array}$ & $\begin{array}{l}\text { Male Managers } \\
\text { Exp }>5 \\
\text { Mean }=31.1500 \\
S D=5.10178\end{array}$ & $\begin{array}{l}\text { Female Managers } \\
\text { Exp }<=5 \\
\text { Mean }=33.3750 \\
\text { SD }=5.44759\end{array}$ & $\begin{array}{l}\text { Female Managers } \\
\text { Exp }>5 \\
\text { Mean }=29.2750 \\
S D=6.95402\end{array}$ \\
\hline $\begin{array}{l}\text { Male Managers, } \\
\text { Exp }<=5 \\
\text { Mean }=30.0750 \\
\text { SD }=5.56725\end{array}$ & $\mathrm{Z}=2.707 *$ & & & \\
\hline $\begin{array}{l}\text { Male Managers, } \\
\operatorname{Exp}>5 \\
\text { Mean }=32.2000 \\
S D=4.60880\end{array}$ & & $Z=-.966$ & & \\
\hline $\begin{array}{l}\text { Female Managers, } \\
\text { Exp }<=5 \\
\text { Mean }=29.6250 \\
S D=4.84470\end{array}$ & & & $\mathrm{Z}=3.253 *$ & \\
\hline $\begin{array}{l}\text { Female Managers, } \\
\text { Exp }>5 \\
\text { Mean }=31.2750 \\
S D=5.03316\end{array}$ & & & & $Z=-1.474$ \\
\hline
\end{tabular}

* Rejection at $5 \%$ level of significance 